\title{
ДИВЕРЗИТЕТ КУЛТУРА НА ПУТУ СВИЛЕ: ОРХОНСКИ НАТПИСИ - ПРВИ ПИСАНИ ДОКУМЕНТИ НА ТУРСКОМ ЈЕЗИКУ
}

\section{Сажетак}

Овај рад бави се Орхонским натписима, првим писаним споменицима на турском језику. Поменути споменици датирају из 8 в.н.е. и потичу са простора данашње Монголије. Писани су тзв. турским рунама. У овом раду ће бити детаљније разматрани ови значајни културни споменици, који представљају почетак развоја писмености код турских народа. Посебно ће бити указано на значај развоја различитих писама којима је бележен турски језик, што је још једно сведочанство о пребогатој културној баштини на Путу свиле.

Кључне речи: Пут свиле, Орхонски натписи, турско писмо, турски народ, културни диверзитет

На Путу свиле, како у давној прошлости, тако и у садашњости (с обзиром да је ова траса и данас веома актуелна, а њен значај ће у савременим геополитичким условима расти у временима која долазе) срећу се и преплићу бројни народи, језици, писма, вере, обичаји, ритуали, веровања. Готово да није могуће појединачно и потпуно прецизно одредити како историјске слојеве, тако и све етничке заједнице, које се срећу трасама Пута свиле.

Поједини народи, који су се у историјској равни јављали и јављали дуж пута свиле оставили су свој дубок печат не само у економском смислу, већ примарно културолошко-цивилизацијски. Један од

Филолошки факултет, Студентски трг 3, 11000 Београд

ema.miljkovic@fil.bg.ac.rs 
тих народа су свакако Турци, у најширем смислу тог појма (иако је наша прва асоцијација када се помену Турци народ који већински насељава данашњу Републику Турски, појам турски народи обухвата бројне групе народа, који се једним етничким именом називају Турцима). ${ }^{1}$

Турски народ, чија је постојбина источна Азија (измеђ река Орхон и реке Јенисеј, северно од Кине), први пут се помиње у документим кинеске провенијенције из 6 века п.н.е. Према речима једног од најпознатијих турских савремених историчара Илбера Ортајлија, „светску историју није могуће писати без историје турског народа“. Ова Ортајлијеве рече односе се примарно на рани период турске историје, када су Турци значајан фактор у историји Кине, Персије, Индије. (Ortaylı, 2015: 14-15)

Многи турколози истичу да порекло турских народа није поткрепљено аутентичним изворима. На основу фрагментарних сазнања извесно је да су турски народи, тј. њихови преци имали значајно место у историји евроазијског региона, много пре него што се њихово народно име појавило у писаним изворима. (Findley, 2005,21)

Најстарије податке о Турцима налазимо код њихових суседа Кинеза чији извори дају податке о појединим турским племенима које су називали Ашин (значење: потомци вучице) још у 2. веку пре н. е. Из ових извора црпимо податке о религији старих Турака, о митологији, календару, државној организацији... Али тек од 6 . века н. е. имамо поузданије податке о Турцима, такође из кинеских списа. (Findley, 2005)

С друге стране, Јован Ковачевић је у свом делу „Аварски каганат" навео да је најстарији помен турских народа забележен код грчког историчара Херодота, у његовом опису Скита из 4. века п.н. е. (Ковачевић,1977, 12) Ипак, ова Ковачевићева тврдња није добила ширу научну потврду.

Ортајли такође наводи помен Турака у византијским и персијским изворима из 6. века. (Ortaylı, 2015, 13-14)

Порекло самог имена Турака је исто тако нејасно и има више ставова по питању код кога се први пут јавило. Код грчких писаца у 6.

1 У англосаксонској литератури се за породицу турских народа користи термин Turkic, док у домаћој оријенталистици (примарно туркологији) таква лингвистичка појмовна динстинкција не постоји. Детаљније видети: М. Теодосијевић, „Турски свет: Турци и турски језик“, Сусрети народа и култура. People and Cultures in Contact, Косовска Митровица: Филозофски факултет Универзитет у Приштини, 2015, 365. 
веку се јављају под именом Турскос, Арапи су их звали Turk и правили сломљени плурал Etrāк ( користећи га у лингвистичком значењу као термин за све турске народе). У кинеским хроникама јавља се као Tu’küe 552. године. (Теодосијевић, 2015) (Findley, 2005)

Први натписи на турском језику, тзв. Гоктурском или турским рунама, датирају из 8. века н.е. и садржали су око 10.000 речи. Ови натписи потичу из долине реке Јенисеј, на простору данашње Монголије. Слова се сатоје од правих црта и не везују се, а пишу се с десна на лево или одозго на доле. Речи се раздвајају са две тачке, има 38 знакова, 4 вокала и 34 консонанта. Како наводи В. Бартолд (W. Barthold) у свом делу Histoire des Turcs d'Asie Centrale, знаци којима су бележени Орхонски натписи су исти као и карактери јенисејског писма које је претходило орхонском. (1945: 10-12)

Детаљнијом анализом порекла писма на којима су ови натписи написани бавио се фински научник Донер, који сматра да је постоји велика сличност између овог писма и натписа на новцу који припада династији Арсакида (претходници Сасанида у Персији, владали су од 3 в.п.н.е до 3. в.н.е). Иранолог Готио сматрао је да се претече јенисејског и орхонског писма могу начи у согдијском писму (Согд је област некадашњег Персијског царства у коме се налазе градови Самарканд и Бухара). Иако поједини иранисти, као француз Готио например, сматрају да и јенисејско и орхонско писмо имају сличности са старијом фазом согдијског писма из 1. в.н.е, није могуће, на основу сачуваних извора, утврдити еволуцију старијег турског писма, те тако Орхонски натписи остају најстарији запис на овом језику. ( (Barhold, 11). Вилхелм Томсен, дански лингвиста, који је рашчитао ове натписе сматра да је орхонско писмо једна од варијанти арамејског писма, а да је свој развој имало кроз пахлави и согдијанско писмо. Ова варијанта турског писма сматра се претечом старог мађарског писма из 10. века. (Scharlipp, 2000) (Sinor, 2002)

У науци су ови натписи познати као Орхонски натписи, и налазе се на надгробним споменицима владара племена Гоктурк, једног од најстаријих турских племена чији помен чувају извори, Голтекину, који је умро 731. године и Билгехану који је умро 734. године.

Турско племе Гоктурк у периоду раног средњег века је једно од најзначајнијих турских племена, који су 552. године основали Царе- 
вину Гоктурк (турски каганат). Ова моћна царевина простирала се у јужном Алтају и на територији данашње Монголије. У њеном суседству живело је и племе Огуза, који су преци највећег броја Турака који живе у данашњој републици Турској, као и других туркојезичких народа Туркмена и Азербејџанаца, на пример. (Đinđić, 1981: 5-6)

Орхонски натписи откривени су приликом једне од експедиција Николаја Михаиловича Јадринцева, руског истраживача, археолога и турколога. Јадринцев, пореклом из Сибира рођен је у Омску 1842 године, где је завршио и гимназију, да би започео студије у Санкт Петесбургу. Већ на самом почетку студија, почиње борбу за модернизацију Сибира, због које је био и осуђен на затворску казну. Ипак, резултат иницијативе Јадринцева и његових сабораца је отварање првог универзитета у Омску (1888). Након акта помиловања за Јадринцева, који објављује цар, овај истраживач, ентузијаста, заљубљеник у родни Сибир улази у државну службу. (https://web.archive.org/ web/20071213021229/http://www.altaiinter.info/project/culture/Researchers/Personnels/Jadrincev/jadr01.htm)

Са Руским географским друштвом 1889. године склапа уговор, те одлази на истраживачку експедицију у Монголију, где је успео да убицира остатке раног средњовековног града Хара-Балгаса, као и монголске престонице Каракорума. У долини реке Орхон, Јадринцев је пронашао два споменика, где су у стенама били уклесани записи који припадају народу Гоктурака и смештају се у период 7-8. века. Ови записи су нешто касније дешифровани трудом данског научника Томсена. (https://web.archive.org/web/20071213021229/http://www.altaiinter. info/project/culture/Researchers/Personnels/Jadrincev/jadr01.htm)

Ово откриће донело је Јадринцеву славу и постало је једна од најзначајнијих научних открића 19. века. Непосредно након открића, 1891. године, Руска академија наука организовала је нову експедицију, коју је предводио признати руски турколог немачког порекла, Радлов. Ова истраживања дала су добре резултати, јер је пронађено још натписа писаних турским рунама, и представљају примарно епитафе предводницима турских племена. Резултати ових истраживања објавио је Радлов у делу „Атлас монголских старина“ (1892-1893), као и у посебном издању посвећеном орхонској експедицији (1892). 
(https://web.archive.org/web/20071213021229/http://www.altaiinter. info/project/culture/Researchers/Personnels/Jadrincev/jadr01.htm)

Поред већ поментуог руског научника Јадринцев, који је својим научничким ентузијазмом открио постојање Орхонских натписа у њиховом публиковању и дешифровању најзначајнији допринос дали су руски турколог немачког порекла Васили Васиљевич Радлов, као и дански лингвиста Вилхелм Лудвиг Петар Томсен.

Васили Васљевич Радлов (рус. Васи́лий Васи́льевич Ра́длов) или Фридрих Филхелм Радлов (нем. Friedrich Wilhelm Radloff) рођен је 1837 године у Берлину. Сматра се оснивачем руске туркологије. Цео свој истраживачки век посветио је истраживању турских народа. Након дипломирања 1858. године, као велики заљубљеник у источне језике, прихвата место професора немачког и латинског језика у сибирском граду Барнаулу. Живећи и радећи у Сибиру, започео је истраживања сибирских народа. Своја истражиања објавио је у монографији Из Сибира (1884). https://radloff.livejournal.com/

У периоду од 1866 до 1907, превео је и објавио многе споменике турског фолклора. Његово најзначајније дело је прво издање Орхонских натписа. Уследио је четворотомни компаративни речник турских језика, објављиван у периоду од 1893 до 1911. Радлов је дао свој допринос основању Руског Етнографског Музеја. Био је руководилац Азијског музеја у Санкт Петерсбургу у пероду од 1884 до 1894. https://web.archive.org/web/20130401080752/http://www.deutschebiographie.de/sfz104169.html

Радлов је помагао руском туркологу Григорију Потањину у његово раду на речницима саларског, западног и источног југурског језика, које Потањин објављује 1893. године у својој књизи „Тангутскотибетанске границе Кине и централне Монголије“. https://web.archive.org/web/20130401080752/http://www.deutsche-biographie.de/ sfz104169.html

Иако је Радлов умро 1918. године у Санкт Петерсбургу, током Стаљиновог режима, крајем тридесетих година 20. века, НКВД и научни радници који су припадали државном апарату оптужују Радлова за пантуркизам. Неки совјетски оријенталисти и турколози који су оптужени да настављају Радлово дело су чак убијени, као што је то био случај са Александром Самовловичем 1938. године. 
https://web.archive.org/web/20130401080752/http://www. deutsche-biographie.de/sfz104169.html

Дански лингвиста Вилхелм Лудвиг Петар Томсен (1842-1927) био је првио турколог који је успео да у потпуности дешифрује старо турско писмо - руне, којима су били писани Орхонски натписи. Томсен је своје образовање 1859. године најпре започео студијама теологија на Данску универзитету, да би се недуго након тога определио за студије филологије. Изучавао је мађарски и финских. Докторску тезу одбранио је 1869. године, на тему немачких позајмљеница у финском језику. Кратко време је предавао грчки језик у једној гимназији у Копенхагену, да бу затим постао професор на Универзитету у Копенхагену. Међу његовим студентима био је познати дански лингвиста Ото Јасперсен. (Brøndal, 1927)

Године 1876. добија позив од универзитета Оксфорд да учествује у серији Илчестерских предавања, које је установио Вилијам Фокс-Странгвејс, четврти ерл од Илчестера (1795-1865). Као резултат тих предавања објавио је књигу „Односи између старе Русије и Скандинавије и почеци руске државе“. (Лондон: Б. Френклин, 1877)

Томсон је у великој мери допринео развоју лингвистике као модерне науке. Његова главна дела односила су се на однос германских, балтичких и индо-иранских утицаја на фински. (Brøndal, 1927, 289391) Иако је, како је већ назначено немачко-руски турколог Радлов први објавио Орхонске натписе, Томсон их је у потпуности рашчитао и објавио на француском (1896: Inscriptions De L'Orkhon Déchiffrées), што представља огроман допринос развоју туркологије као науке.

Поред великог лингвистичко-филолошког, Орхонски натписи имају и историографско-културолошки значај. На основу њих се може, барем у основним цртама, реконструисати друштвене структура турских ханата који су, у периоду 7-8. века, живели на границама Кине. Ови значајни писани споменици пружају обавештења о номадском начину живота. Оно на шта Бартолд скреће пажњу то је улога хана, као предводника у организацији Гоктурака. По друштвеним законитостима код номадских друштава не постоји никакав облик државне организације, нити хијерархије. Уосталом, са тим проблемом ће се и моћни Турци Османлије сусретати током готово читавог постојања 
Царства, јер азијска номадска племена, без обзира што су била турског порекла, нису желела да прихвате ауторитет централне власти. Тако и код хановима (предводницима) Гоктурака ${ }^{2}$ није било лако да наметну свој ауторитет и организују управу над својим поданицима. Најчешће би они наметали свој ауторитет након неке извојеване војне победе. На тај начин, припадници племена су били стављени, како размишља Бартолд, пред свршен чин. (Barhold, 8-9)

\section{Литература:}

Barhold, W. Histoire des Turcs d'Asie Centralrale. Paris: Adrien - Maisonneuve, 1945. Emprimé Brøndal, Viggo. „"'L'œuvre de Vilhelm Thomsen.“ Acta philologica scandinavica 2 (1927): 289-381. Emprimé. Cooper, J. S. „Babylonian beginnings: The origin of the cuneiform writing system in comparative perspective." Stephen Houston. The First Writing: Script Invention as History and Process. Cambridge: Cambridge University Press, 2004. 58-59. Printed.

Đinđić, Slavoljub. Knjiga Dede Korkta. Herojski ep oguskih Turaka. Beograd: Narodna knjiga, 1981. Štampano.

Findley, Carter Vaughn. The Turks in the World History. Oxford: Oxford University Press, 2005. Printed.

George Campbell, Christopher Moseley. The Routledge Handbook of Scripts and Alphabets. London: Routledge, 2013. Printed.

Kara, Gyorgy. „Aramaic scripts for Altaic languages." Peter Daniels, William Bright,. The World's Writing Systems. New York: Oxford University Press, 1996. 536-557. Printed.

Mabry, Tristan James. Nationalism, Language, and Muslim Exceptionalism. Philadelphia: University of Pennsylvania Press, 2015. Printed.

Ortaylı, Ilber. Türklerin tarihi. Istanbul: Timaş Yayınları, 2015.Printed

Samoylovitch, A. „Turks.“ First Encyclopaedia of Islam , Vol. VI. Leiden: Brill, 1913-1936 (1993). 911. Printed.

Scharlipp, Wolfgang. An Introduction to the Old Turkish Runic Inscriptions. Verlag auf dem Ruffel: Engelschoff, 2000.Printed

Sinor, Denis. „Old Turkic.“ History of Civilizations of Central Asia. Paris: UNESCO, 2002. 331-333. Printed. Теодосијевић, Мирјана. „Турски свет: Турци и турски језик.“ Сусрети народа и култура. People and culture in contact. Косовска Митровица: Филозофски факултет Универзитет у Приштини, 2015. 361-371.Штампано

https://web.archive.org/web/20130401080752/http://www.deutsche-biographie.de/sfz104169.html https://radloff.livejournal.com/

Гоктурци су били група турских племена која је живела у централној Азији. У кинеским изворима се помињу у 6. веку, и врло брзо су, захваљујући својим војничким вештинама, успели да освоје значајну територију, као и да контролишу трговину на том делу Пута свиле. 


\title{
Ema Miljković
}

\section{CULTURAL DIVERSITY ON THE SILK ROAD: ORHON INSCRIPTIONS-FIRST WRITTEN DOCUMENTS IN TURKISH LANGUAGE}

\begin{abstract}
Summary
The Turkish people, whose homeland is East Asia (between the River Orhon and the Yenisei River, north of China), was first mentioned in the 6-century documents of the Chinese provenance. The first inscriptions in the Turkish language, in the Gökturks letters, called also the Turkish runes, date back to the 8th century A.D. and contained about 10,000 words. These inscriptions originate from the Yenisei River valley, in the today's Mongolia. The letters are made of straight lines and do not bind, and are spelled from right to left or from up way down. Words are separated by two points, the has 38 characters, 4 vocals, and 34 consonants.

In the science writings, these inscriptions are known as Orhon Inscriptions, and they were found on the tombstones of the two Gökturk rulers, Göltekin, who died in 731 and to Bilgehan, who died in 734.

This work will further review these significant cultural monuments, which represent the beginning of literacy with the Turkish people. It will especially indicate the importance of developing different letters of Turkish language, which is another testament to the richness of cultural heritage on the Silk Road.
\end{abstract}

Key words: The Silk Road, The Orhon Inscriptions, Turkish letters, Turkish people, Cultural Diversity 